Martin D. Henry (ITQ, vol. 63/3, 1998, 250-62)

\title{
The Enlightenment and Romanticism from a Theological Perspective
}

\section{Introduction}

In a previous article, ${ }^{1}$ I suggested how certain aspects of postmodernist thought might be regarded as secularized expressions of theological ideas rooted in the Judaeo-Christian tradition. In this article, I attempt to look back briefly at the two great modern movements of Western thought and sensibility known as 'the Enlightenment' and 'Romanticism', to see how they too might be viewed as secularized forms or transformations of Judaeo-Christian theological themes. In later articles, I hope to extend this line of enquiry further, to see if it could be used to interpret thinkers like Hegel and Marx, whose impact on modernity may owe less to their own originality than to the power of the Western religious and theological tradition from which they both sprang.

The Enlightenment

To begin with the Enlightenment, it is of some interest to note that the term 'Enlightenment' itself was little used in English before the twentieth century, when it displaced the older phrase, the 'Age of Reason'. This expression, which had been used to characterize the world of classical rationalist philosophers like Descartes or Leibniz, was felt to be inappropriate as a description of the 'Enlightenment'. Figures like Descartes, with his belief in man's innate ideas, or Leibniz were considered by the philosophes (as the French representatives of

1 'God in Postmodernity', ITQ, 63 (1998) 3-21. 
the Enlightenment were known) to have simply replaced the old dogmatism of the Church with a new philosophical dogmatism of their own based on a priori principles that lacked any empirical underpinning. ${ }^{2}$

What then was the Enlightenment? The first thing to say is that it was not an organized movement, but more a pervasive mood of freethinking, critical questioning, a mood that spread throughout the Western world from the seventeenth century onwards. It was the intellectually revolutionary period in modern times, that began in England in the middle of the seventeenth century, reached Scotland, America and France in the eighteenth, and spread finally to Germany and the rest of Europe by the end of the eighteenth century. The upheavals it helped set in train included the American and French Revolutions, and the Napoleonic wars. In science it was an age of experimentation and discovery through free rational enquiry. A corollary of this was that the controlled search for verifiable truth undermined the status of any purely speculative a priori reasoning processes, whose results could not be empirically checked, and weakened even further what remained of the prestige of tradition. ${ }^{3}$ In philosophy and religion the Enlightenment - or the Aufklärung, to use the frequently employed German designation for the movement - was a time of radical questioning of such traditional sources of authority as the Church or the Bible. And in politics it was the period when the established order of things, the ancien régime, was subjected to a remorseless and finally destructive critique, as being despotic and irrational. Religious intolerance, obscurantism and

2 Cf. Jeremy Black and Roy Porter (eds.), The Penguin Dictionary of Eighteenth-Century History (London: Penguin, 1996), 226.

3 The clash between traditional wisdom and free enquiry is, of course, much older than the Enlightenment. It is indeed difficult, perhaps impossible, to pin down 'the unidentifiable moment when independent thought, disregarding the mythological legacy as a source of authority, arose in our civilization' (Leszek Kolakowski, Metaphysical Horror, Oxford: Blackwell, 1988, p. 2). Karl Jaspers notably, with his concept of an 'axial period' (Achsenzeit), which he developed in Vom Ursprung und Ziel der Geschichte, 1949 (The Origin and Goal of History, 1953), located a momentous change in world culture - not just in ancient Greece - roughly in the period 800-200 BC; cf. also Arnaldo Momigliano, Essays in Ancient and Modern Historiography, Oxford, 1977, 9. In more recent Western history, the period when observation and experimentation began to be favoured over authority alone as a route to truth can be dated roughly to the twelfth and thirteenth centuries. Figures like Robert Grosseteste (c.1170-1253), Roger Bacon (c.1220-c.1292), Albertus Magnus (c.1206-1280), and the latter's most celebrated pupil, St Thomas Aquinas (1224/5-1274), consolidated the new trends. See Felipe Fernández-Armesto, Truth. A History and a Guide for the Perplexed (London, 1997), 146ff. 
political tyranny were to be replaced by tolerance, open enquiry and freedom, and the external authority of tradition overthrown in favour of individual autonomy. No ideas were to be any longer held as sacrosanct or beyond the range of criticism. Free examination of all religious and intellectual positions, rather than a slavish adherence to the orthodoxies and pieties of the past, was the new ideal, almost the watchword or the war cry of the Enlightenment.

The Enlightenment differed, of course, from place to place - it might even be more accurate to speak of 'Enlightenments' - but in general it was characterized by widespread confidence in the power of human reason, ${ }^{4}$ and an equally important belief in the universality of human reason, and indeed of human nature. ('In all nations and ages,' according to David Hume, 'human nature remains still the same.'5) For reason was held to be 'basic to human nature, and with reason it was possible to guarantee universal agreement of questions about the world as well as about matters of mathematics.' ${ }^{6}$ Such at least was the Enlightenment's conviction in its most optimistic moments.

The Enlightenment was also a period of experimentation with new forms of human association. ${ }^{7}$ Above all, it was a period of intense optimism about the

4 The Enlightenment's understanding of 'reason' did not, of course, go unchallenged even in the time of the Enlightenment itself. 'Opposition to the central ideas of the French Enlightenment, and of its allies and disciples in other European countries, is,' as Isaiah Berlin has written, 'as old as the movement itself', Against the Current, Oxford, 1981, 1. Berlin's essay 'The Counter-Enlightenment', which opens with this quotation, is instructive on the Enlightenment's failure, even in its heyday, to silence all opposition. (In that sense, curiously enough, it resembles Christianity itself, suggesting perhaps that neither 'reason' nor 'religion' alone can ever fully accommodate the perplexities and perils of human existence.) Enemies of Enlightenment rationalism often echo Pascal's complaint (The heart has its reasons which reason knows nothing of) against the Cartesian monopoly of 'reason' by the scientific method. More recently, however, Enlightenment 'reason' itself has begun to look shaky, even in the eyes of its defenders. As Ernest Gellner wrote in 1957 (in 'Is belief really necessary?', The Devil in Modern Philosophy, London, 1974, p. 61): "In modern times, Faith has lived in a kind of Strindbergian ménage with Reason. The final possible cause of a decline of belief may be that this partner is in eclipse too. Not merely no longer a faculty, and deprived of normative authority by Hume, it has also lost much of its status as a kind of Censor of cognition. . . ('Believing in Reason', once a paradoxical expression, seems appropriate now.)”

5 Quoted by Robert C. Solomon, Continental Philosophy since 1750 (Oxford, 1988), 9.

$6 \quad$ Ibid., 10.

7 The first socialist communes of Charles Fourier (1772-1835) in France and Robert Owen (1771-1858) in England were inspired by Enlightenment ideals. 
future, belief in progress, and an almost unlimited faith in the power of human beings to eradicate misery and eventually to create happiness on earth by the persistent application of their reason and will to the solution of human problems. To that extent its greatest quarrel with Christianity was the latter's emphasis on 'original sin' ${ }^{8}$ This doctrine was a thorn in the Enlightenment's flesh, for it appeared to condemn the human race to a sentence of permanent imperfection within history, and such a judgement was anathema to the Enlightenment. In theological terms the Enlightenment can be viewed as a neoPelagian, and not entirely surprising, reaction to the extreme pessimism of the sixteenth-century Reformation which had emphasized too one-sidedly the corruption of human nature and the misery of man without God. ${ }^{9}$

Because of its avowedly anti-Christian slant, the Enlightenment is often considered to be anti-religious. Yet nothing could be more misleading, for the Enlightenment was obsessed with religion, and keen to develop a rational brand of it. Very few representatives of the Enlightenment would have thought of themselves as atheists. The Enlightenment saw itself, rather, for the most part as combating only 'revealed' religion, ${ }^{10}$ religion that claimed to have a privileged access to truth. For the Enlightenment this was simply 'superstition', and had to be rejected. Rationally tested religious doctrines could, on the other hand, be accepted. But while the Enlightenment tended to acknowledge a rational doctrine of God, it saw the world itself as the sphere of human endeavour, had a

8 In this regard it is interesting to note that while some Enlightenment figures might have been sceptical about the ultimate scope of reason, their scepticism did not generally extend to the notion that man might be morally less than admirable. Thus, as R.C. Solomon writes (op. cit., 14), whereas a David Hume "did not have unqualified confidence in reason, he did share with Rousseau a profound confidence in the human sentiments. 'Reason is and ought to be the slave of the passions', he wrote in his Treatise of Human Nature [Oxford, 1951, 451], and so expressed a thesis that would have great appeal to the romantics. .."

9 If this interpretation of the Enlightenment is correct, it might lend some weight to Hegel's view of history as advancing in a dialectical movement, whereby unsatisfactory states of affairs are changed by critical reaction to their perceived shortcomings.

10 David Hume (1711-1776) subjected the ideas of revelation and miracles - two mainstays of Christian apologetics - to a withering critique (cf. Justin Wintle, Furious Interiors. Wales, R.S. Thomas and God, London, 1997, 411). Hume, of course, went much further than many other Enlightenment thinkers in his critique of religion, in that 'he argued systematically that reason could undermine both natural and revealed religion' (John P. Wright, in: J. Black and R. Porter, eds., op. cit., 338, referring to Hume’s Enquiry concerning Human Understanding, published in 1748). 
'keen sense of humanity as part of nature', ${ }^{11}$ and regarded humanity's fate as an experiment to be conducted by human beings alone: 'Pope's declaration that "the proper study of mankind is man" became the working definition of the Enlightenment intellect.' 12

Somewhat oddly however - given its anti-Christian bias - there is an almost messianic quality about the Enlightenment enterprise, (a quality to be found also later in Hegel and, to a very much greater extent, in Marx). How else might one describe the Enlightenment's conviction that the revelation of the final truth about the world was at hand? For the men of the Enlightenment saw themselves as liberators, potentially of the whole world. They sensed that the Enlightenment represented a clean break with a corrupt, benighted, and barbarous past, and the inauguration of a period of radical change, freedom and progress. ${ }^{13}$ This is doubly ironical, given that it was the Enlightenment's theologians who regarded the eschatological elements of Christianity, like so many of its other aspects, such as miracles for example, as awkward relics from the past and discarded them, in order to leave room only for a religion of pure reason. ${ }^{14}$ But as tends to happen, when an important aspect of a historical tradition is neglected, it does not cease to exist, it merely changes its appearance and re-emerges in a new, often unexpected, guise. This, I think, is what happened at the Enlightenment. The messianic potential of Judaism and the eschatological beliefs of Christianity were suppressed, only to re-surface in the Enlightenment's politically most robust progeny of the nineteenth and twentieth centuries: Marxism. ${ }^{15}$

11 Solomon, op. cit., 10.

12 Solomon, op. cit., 9.

13 Cf. Ernest Gellner's remarks (The Devil in Modern Philosophy, London, 1974, 119) on the Enlightenment's view of history: “ . . . [T] he men of the Enlightenment . . . were rather inclined to have what one might call a 'two basic states' view of the universebefore and after, as it were, the Enlightenment. (Before there was darkness and superstition; afterward, there was light. The 'dual state' vision is perhaps itself something inherited from religion.)" Gellner also argues intriguingly (Postmodernism, Reason and Religion, London, 1992, 57f.) that "the idea of the uniqueness and universality of truth," characteristic of Western religious thought, may have been inherited from this source by the Enlightenment: "Rationalism was the continuation of exclusive monotheism by other means” (ibid., 58).

14 Kant's last full-scale work, we recall, was entitled: Religion within the Limits of Reason Alone (1793).

15 Cf. John Macquarrie's observation: 'When the liberal theologians of the Enlightenment threw out the radical-apocalyptic strains in Christianity as no longer intellectually 
To repeat, Enlightenment thinkers were cosmopolitan and universalist in their humanism, and implacable enemies of claims to any exclusive access to truth. For such claims, they felt passionately, had been at least partly responsible for the terrible wars of religion that had devastated Europe in the sixteenth and seventeenth centuries. With its confidence that anything worth knowing could be known only by experience, observation and reason, and that reason was the same everywhere, it was hardly surprising that the Enlightenment felt certain that everyone would eventually, after enough education and debate where necessary, come 'to believe in the same scientific truths, follow the same moral guidelines, endorse the same political structures, and worship the same god or gods.' ${ }^{16}$ The optimistic convictions and positive ideals of the Enlightenment are, finally, of much more than purely historical interest, for in many respects they are still alive today. ${ }^{17}$

There were however also some shadows on the Enlightenment landscape: such a typical figure of the Enlightenment as Voltaire (1694-1778), for example, was much exercised by the question of evil, while from a somewhat different direction the writings of the Marquis de Sade (1740-1814) pointed ominously to the possibilities of nihilism slumbering in the innocent-sounding proposition that ultimately human beings themselves were, or at least should be, in control of their own destiny, and should make unfettered use of their own powers. ${ }^{18}$ If one recalls Kant's famous definition of 'enlightenment' (1784), ${ }^{19}$

respectable, they were ensuring that these strains would develop a life of their own, but a life divorced from the religious context within which they had originated. No book of the Bible was more embarrassing to liberal theologians than the Revelation of St John the Divine. For Engels, on the other hand, "this book is worth more than the rest of the New Testament put together"' (J. Macquarrie, 'Philosophy and Religion in the Nineteenth and Twentieth Centuries: Continuities and Discontinuities', The Monist, 60 (1977) 269f.; the final reference is to Karl Marx and Friedrich Engels, On Religion, New York: Schocken Books, 1964, 212). Solomon, op. cit., 11.

17 Cf. Roy Porter: 'The rise of the modern secular intelligentsia, belief in basic liberal and personal freedoms, the role of the press and the media, and the fundamental conviction that man must forge his own destiny through industry and intellect - all these are the legacies of the Enlightenment' (The Penguin Dictionary of Eighteenth-Century History, 228).

18 Cf. the thesis of Horkheimer and Adorno in their Dialektik der Aufklärung 1947 ('Dialectic of Enlightenment'): 'The apparent amoralism in his [Sade's] writings, which celebrate the unrestrained self-indulgent search for self-gratification, is the natural result of pursuing Enlightenment ideals . . I It is an astonishing claim, and not 
then one might argue that it is precisely the ideal encapsulated in Kant's dictum, interpreted no doubt against the latter's best intentions, which ultimately lies behind de Sade's flamboyant, provocative and dangerous experimentation with life and thought. Finally, Hume himself - despite being in many respects a quintessentially Enlightenment figure ('to be the "Newton of the moral sciences" was the great aim of David Hume' ${ }^{20}$ ) - can in retrospect be seen as helping to undermine its rationalist pretensions through the impulse he gave to radical scepticism in his own writings. It was indeed the spectre of such scepticism ('the euthanasia of pure reason' ${ }^{21}$ ) that roused Kant, on his own admission, into action in defence of the Enlightenment, but whether he ultimately overcame Hume's extreme scepticism ${ }^{22}$ or exacerbated it, is an open question.

What is clear, though, is that Kant (1724-1804) mounted the most intellectually powerful defence of the Enlightenment that it had ever received. This occurred at the end of the eighteenth century, which itself is no doubt a sign that by that stage it needed some serious shoring up. ${ }^{23}$ For the truth is that

uncontroversial' (T. Mautner, ed., The Penguin Dictionary of Philosophy, London, 1997, 497).

“Enlightenment is man's release from his self-incurred tutelage. Tutelage is man's inability to made use of his understanding without direction from another. Self-incurred is this tutelage when its cause lies not in lack of reason but in lack of resolution and courage to use it without direction from another. Sapere aude! 'Have courage to use your own reason!'- that is the motto of enlightenment" (Kant, 'What is Enlightenment', in Isaac Kramnick, ed., The Portable Enlightenment Reader, New York, 1995, p. 1).

20 The Penguin Dictionary of Eighteenth-Century History, 227. Apparently Sigmund Freud had a similar aspiration; cf. Solomon, op. cit., 141: 'In 1895 [Freud] wrote a short book, Project for a Scientific Psychology, in which he expresses his ambition (shared with Hume) to become the Isaac Newton of the mind.' Freud's faith in the ultimate power of reason to illuminate the murky depths of the mind marks him as still, long after the heyday of the Enlightenment, a representative of its ideals (cf. Solomon, op. cit., 146).

21 Quoted by Felipe Fernández-Armesto, Truth, 168.

22 Bertrand Russell remarked on Hume's scepticism: 'Hume’s skeptical conclusions ... are equally difficult to refute and to accept. The result was a challenge to philosophers, which, in my opinion, has still not been adequately met' (A History of Western Philosophy, New York, 1945, quoted by R.C. Solomon, Introducing Philosophy, Fort Worth, 1997, 168). 
the Enlightenment had begun to come under attack, precisely in Germany, ${ }^{24}$ from a counter-movement, namely Romanticism, which eventually overtook the Enlightenment, even though it did not of course destroy it. It is indeed somewhat ironic, as R.C. Solomon points out, 25 that the Enlightenment in fact received its most serious defence in Germany, where, unlike in England and France, it had never really completely caught on. For the cosmopolitanism, rationalism and universalism of the Enlightenment, it has been argued, ${ }^{26}$ were more easily accepted in England or France, than in Germany, for the simple reason that both England and France had themselves universal cultural pretensions in the heyday of the Enlightenment (and subsequently also). Another irony, then, of the Enlightenment is that its universalism may itself be the reflection of the ambitions of specific individual nations.

The fragmented state of Germany, on the other hand, appears to have hindered the development of the rationalist and universalist aspirations one finds in England and France, but it did foster, by contrast, the reaction to the Enlightenment expressed by Romanticism. The latter was, to some extent 'a rejection of the political imperialism of the more powerful Enlightenment nations, and a defence of traditional religion against excessive rationalism. ${ }^{27}$ Fragmented Germany, in other words, experienced the Enlightenment 'as a threat', and Romanticism, then, 'was first of all an expression of nationalism and provincial self-assertion.' 28 Where the two movements resembled each other, apart from having 'the same social origins as expressions of middleclass_-or more properly bourgeois (bürgerlich)—ideology', ${ }^{29}$ was in projecting their concerns and convictions on to the whole world: the Enlightenment projecting its rationalist, progressive creed, Romanticism its subjective fears and needs and its inarticulate, infinite yearnings.

The growth of the bourgeoisie, coinciding with the decline in monarchical and aristocratic power in Europe in the course of the eighteenth century, goes

\footnotetext{
24 ' [I]t can be argued that resistance to Enlightenment ideals reached similar strength in England, America, and France only very recently, perhaps only within the past few decades' (Solomon, op. cit., 11).

25 Op. cit., 11.

26 Cf. Solomon, op. cit., 12.

27 Solomon, op. cit., 13.

28 Op. cit., 12.

29 Op. cit., 13.
} 
some way to account for the self-assurance, or, in Solomon's words, the 'adolescent arrogance appropriate to their ascendancy,' 30 that was exhibited by the Enlightenment philosophers and their successors. Borrowing suggestions from Marx and Freud, we might say that once the bourgeoisie had acquired the economic power to emancipate itself from traditional ecclesiastical and politically absolutist controls, it then rebelled spiritually and intellectually against its former 'parents' or 'guardians', creating firstly the Enlightenment, which eventually disenchanted the world, and subsequently Romanticism, which was the attempt to re-enchant it.

The untameable, inscrutable nature of reality, however, was in the long run to prove fatal to the Enlightenment and to its dream of controlling the world. The assumption that the world was clear, or could be made clear, by rational, empirical investigation, and the even more extravagant assumption that human reason, being the same everywhere, could be trusted to bring about harmony and agreement among people, were both flawed. To say nothing of the possibility that language itself - because of its own incurably self-referential character might in the end turn out to be incapable of explaining the world objectively. ${ }^{31}$ Certainly what is beyond dispute, what the Enlightenment did not bargain for, was 'that not everyone would in fact agree, indeed would not even agree with the ideals of rationality, universality, and autonomy. The result would be the most pig-headed disagreements in history, no longer caused by pride, avarice, or religious competition, but by ideology bolstered with confidence in "selfevident" truths about the nature of "human nature"., 32

For all their differences, both the Enlightenment and Romanticism thought that through the individual the totality could be understood. But the Enlightenment believed all 'selves' were essentially alike and could think according to the same universal laws of ratiocination in order to reach the same

$30 \quad$ Op. cit., 13.

31 To accept the limits of human knowledge, which were so painstakingly delineated by Kant, to suspect that there are dimensions of reality we will never know, or, that there is, in the words of R.S. Thomas's poem 'Phew!', 'a knowledge/not to be known' (see J. Wintle, Furious Interiors, 413), is to realize that 'we know so little that even if we did know everything we still wouldn't have the means of knowing that we know' (J. Wintle, ibid., 414, interpreting R.S. Thomas). In theological language, we could say that the creature cannot possess the mind of the Creator, although it should be added that since Genesis neither has the temptation to do so ever been definitively extinguished ... Solomon, op. cit., 11. 
conclusions about the universe. The Romantics, by contrast, were to stress the uniqueness of each individual 'self' and its corresponding power to fathom all reality by a uniquely authoritative vision or intuition. Kant, again against his own intentions, set the scene at the end of the eighteenth century for the expansion and development of the thinking subject (or self), so that it ultimately laid claim to transcendental and universal significance. After Kant, the German Idealists, who were deeply influenced by Romanticism, spelt out in ever greater detail how the self reflected, and in some sense was the whole of reality. This was the nineteenth century's way of interpreting an ancient idea going right back via St Thomas Aquinas to Aristotle, according to whom 'even the finite spirit is "quodammodo omnia (in a way all things)", 33 and going back also, even more pertinently, via Jakob Boehme, Nicholas of Cusa, Meister Eckhart, John Scotus Eriugena and Plotinus to Plato. ${ }^{34}$ In this latter, more mystical, perspective the relationship between man and God, contingency and necessity, creation and creator, hovered uneasily on the brink of dissolution: man was always in danger of merging completely into God.

As a final reflection on the Enlightenment, the question raised by John Macquarrie is worth pondering:

In Nietzsche we reach the apotheosis of the human autonomy which Kant had proclaimed as the essence of Enlightenment. Or if we want to trace the origin of the superman even further back, do we find it in that moment at the beginning of the modern period when Descartes decided that the only reality we can really trust and make . . . the foundation for everything else is human self-consciousness? So Heidegger thought when he wrote, 'Modern metaphysics first comes to the full and final determination of its essence in the doctrine of the superman. In that doctrine, Descartes celebrates his supreme triumph.' ${ }^{35}$

\section{Romanticism}

33 Walter Kasper, The God of Jesus Christ, tr. M.J. O’Connell (London, 1983), 154.

34 Cf. Leszek Kolakowski, Main Currents of Marxism, vol. I (Oxford, 1978), chap. 1.

35 J. Macquarrie, Jesus Christ in Modern Thought (London, 1990), 365; the Heidegger reference is to Nietzsche, Harper \& Row, 1982, vol. 4, 28. 
Writing in 1801 in his Neology or Vocabulary of New Words, the French commentator Louis-Sébastien Mercier (1740-1814) wrote on the term 'romantic': 'you can feel it but cannot define it' ${ }^{36}$ If one were, nevertheless, to try to characterize Romanticism, one could say that it was a revolt 'against the tyranny of reason and classicism.' ${ }^{37}$ The Romantics 'challenged the supremacy of reason as the foundation of knowledge,' 38 'seeing Western Enlightenment as narrow and limited.' 39 They were not convinced that a methodically applied rationalism alone, together with empirical observation of the external world, could do justice to the full reality of human existence. They suspected, in other words, that there was more to reality than what a calculating and exploitative reason could detect.

Keats's complaint 'that reductive Newtonian science demystified the rainbow' 40 implied that a rationalistic interpretation even of non-human nature left essential aspects of the truth unrecognized. And when Wordsworth, reechoing ancient misgivings about 'the tree of knowledge', protested: 'We murder, to dissect', he was giving a dramatic warning about the destructive cost of science and at the same time drawing attention to the unbridgeable gap, as he saw it, between life and thought, or reason's inability to do justice to lived experience. At a more sombre and yet practical level of abstraction, as it were, Blake's reference to the "“dark, Satanic mills" was an apocalyptic vision of the industrial revolution,' ${ }^{41}$ that is to say a realization of the disastrous price to be paid in human terms for the industrial progress so vaunted by the Enlightenment. The Romantics, in short, discovered and lamented many features of what the German sociologist Max Weber (1864-1920) was to call

The Penguin Dictionary of Eighteenth-Century History, 646. This is reminiscent of what St Augustine said about time (Confessions xi. 14): 'I know very well what it is, provided that nobody asks me; but if I am asked and try to explain, I am baffled.'

The Penguin Dictionary of Eighteenth-Century History, 647. Classicism is the term normally used to refer to art whose creation is governed by strict rules of composition, which eventually succeed in becoming established as canonical in their own particular spheres. The French 'classical age' in the seventeenth century, for example, set the standards for artistic endeavour and taste until well into the eighteenth century both in France and in countries like Germany which admired French culture. 'Classicism', which often becomes established in the fields of literature and painting and architecture, implies a deep respect for strict formal discipline in the execution of any work of art. Ibid., 648.

Ibid., 647.

Ibid., 648.

Ibid., 648. 
the 'disenchantment of the world', for which the Enlightenment was held to be responsible.

Their response to disenchantment was political as well as intellectual. The Romantics challenged the status quo. But their challenge sprang in part from a critical attitude which united them to, rather than separated them from, the Enlightenment. ${ }^{42}$ When the critical spirit of the Aufklärung moved from the salon to the street, the modern, continental revolutionary tradition was born and it gradually spread, like a disease or a gospel, throughout the whole world. And in a move that was not unconnected with its potentially revolutionary, political aspirations, Romanticism fostered a new interest in the past as the place where alternative ways of organizing life might be found. 43

But for the Romantics, unlike for the representatives of the Enlightenment, feeling, ${ }^{44}$ personal insight or introspection was of much more value than the objectivity allegedly provided by external ${ }^{45}$ observation and by the following of what were considered by the Enlightenment to be universally valid rational modes of thought. If one wished to understand the world, the Romantics argued, one had to start with the individual self. ${ }^{46}$ Believing in the

42 The critical tenor of, say, Marx's writings is indebted, one might say, intellectually to the Enlightenment and politically to Romanticism.

43 It might be argued that the catastrophic Khmer Rouge experiment in Cambodia in the 1970s to re-create a purely agricultural age, presumed to have existed prior to modern, industrialized times, owes something to Romantic, and specifically Rousseauesque ideas. The Romantic Catholicism of the nineteenth century also looked back to an (idealized?) past, in its search for new bearings in an unsettled age.

44 Cf. Faust's plausible defence of "religious feeling” in the "Marthens Garten" scene of Goethe (1749-1832), Faust Part 1, in answer to the so-called "Gretchen-question" on the nature of Faust's religion (cf. M. Beddow, Goethe Faust 1, London, 1986, 73): “ . . . Gefühl ist alles;/ Name ist Schall und Rauch,/ Umnebelnd Himmelsglut” (“ . . . Feeling's surely all./ Names are but noise and smoke,/ Obscuring heavenly light”, tr. P. Wayne, Harmondsworth, 1971, 153); or Chateaubriand's (1768-1848) statement of faith (cf. The Oxford Dictionary of the Christian Church, Oxford, 199733, 326), which resolved the personal crisis brought on by the deaths of his mother and sister: "Ma conviction est sortie du coeur. J'ai pleuré et j'ai cru" ("My conviction came from the heart. I wept and I believed"). And, of course, Schleiermacher (1768-1834) is (in)famous for exalting "feeling” above rational thought in his theology.

45 Wittgenstein, one might note in passing, was to question the meaning of any innocent use of the term 'external': "Why, Ludwig Wittgenstein once wondered, do we speak of the 'external' world? External to what?” (T. Eagleton, The Illusions of Postmodernism, Oxford, 1996, 13).

46 Cf. The Penguin Dictionary of Eighteenth-Century History, 648. 
'unfathomable nature of human genius,' ${ }^{47}$ the Romantics challenged - quite logically from their own point of view - 'the authority of society over that of the individual,' ${ }^{48}$ and emphasized rather the importance of the self, qua self, and the authenticity of its experience. 49

More often than not the Romantic (especially artistic) self was that of 'the tortured genius, a tragic misfit in a world prone to crass materialism and pragmatism. Originality won status as the hallmark of genius.' 50 Yet though finding themselves generally to be outcasts from normal society, Romantic artists nevertheless considered that they also had a mission to society. For Shelley, poets were 'the unacknowledged legislators of the world'. Even in reading Marx, in many respects an unpoetic soul, one is constantly reminded of how he must have seen himself as a great visionary artist, using the materials of history to mould or re-mould humanity into its final, perfected form. His famous eleventh 'thesis on Feuerbach' could serve as a statement of his own ambition: 'The philosophers have only interpreted the world in various ways; the point is, to change it.' To that extent, Marx should be seen as a Romantic. For one of the salient features of the Romantic movement is its glorification of the notion of human creativity, evident in the way the 'myths of creation and re-creation . . . became central to romanticism - Faust, Prometheus and Frankenstein.' ${ }^{51}$ For Keats, the world was 'The vale of Soul-making', not - as Christianity had traditionally held, and still holds - the theatre where God interacts with his creatures. It might, indeed, be worth asking whether Christianity's decline in the West since the Enlightenment, and the concomitant loss of belief in the world as dependent on a transcendent Creator, may have cleared the way for an emphasis

\footnotetext{
$47 \quad$ Ibid., 648.

$48 \quad$ Ibid., 648.

49 The Romantics' belief in the overriding significance of experience was put memorably by Keats when he wrote that, 'Nothing ever becomes real till it is experienced-even a proverb is no proverb to you till your life has illustrated it' (The Oxford Dictionary of Quotations, Oxford, $\left.1986^{3}, 294\right)$. The impact of such convictions on religion is hard to overestimate. If experience counts as the principal criterion of value, then a religion that can no longer be experienced as true or meaningful is in trouble. This is precisely Christianity's, and specifically, Catholicism's dilemma in the face of the widespread contemporary inability to find the Catholic Church's rituals, rules and doctrine relevant to modern experience.

50 J. Belchem and R. Price (eds),The Penguin Dictionary of Nineteenth-Century History (London, 1996), 535.

51 The Penguin Dictionary of Eighteenth-Century History, 226.
} 
on free human creativity to emerge, all the more so since in the Judaeo-Christian tradition man was held to be made in the image of God the Creator.

Such creativity would also, of course, have more proximate causes. It could spring, for example, from the individual's sense of disillusionment with, and yet feeling of responsibility for, a society deemed to be inherently corrupt and in dire need of reform. (From this time too, indeed, might be tentatively dated the emergence of the 'modern theologian' - made in the image of the secular intellectual - who is usually somewhat on the margins of things or ahead of his times, and inadequately understood, but who sees his task as rescuing a corrupt, or at least a deviant Church from disaster or irrelevance.) From Rousseau onwards, society was considered by many intellectuals to be responsible for the corruption of the individual, who had been born in a supposed state of natural innocence. This, in turn, provoked a desire to reinstate an allegedly original, but subsequently lost, sense of unity between man and his environment. Clear echoes of the Christian story of Fall and Redemption are here unmistakably present. And in thinkers like Hegel there is, in fact, an explicit longing to overcome the split (or alienation) between the individual self and society, and to bridge the gulf between humanity and nature. These ideas lived on, albeit transformed, 52 even in Nietzsche, ${ }^{53}$ who otherwise saw himself as the very antithesis of Hegel, and also in Marx, ${ }^{54}$ another resolute anti-Idealist, at least in intention.

52 Transformed, in the sense that the re-constituted unity of man and nature which Nietzsche envisages is heroic and non-metaphysical, whereas, by constrast, for traditional Idealism it is, according to Nietzsche, metaphysically reassuring and even flattering to man's self-understanding.

53 In The Gay Science §109, for example, he writes: "When will we complete our dedeification of nature? When may we begin to 'naturalize' humanity in terms of a pure, newly discovered, newly redeemed nature?” (tr. W. Kaufmann, New York, 1974, 169). Again, in Beyond Good and Evil, §230, we read: "To translate man back into nature; . . . to see to it that man henceforth stands before man as even today, hardened in the discipline of science, he stands before the rest of nature . . " (tr. W. Kaufmann', Basic Writings of Nietzsche, New York, 1968, 351).

54 For Marx, more explicitly and more unproblematically than for Nietzsche, the unity of man and nature is a form of humanism, whereby nature is seen as subservient to human needs and ends ('the whole of so-called universal history is nothing but the formation of man by human labour, the shaping of nature for man's sake': from K. Marx, Economic and Philosophical Manuscripts of 1844, quoted by L. Kolakowski, Main Currents of Marxism, Oxford, 1978, vol. 1, 137, as cited in J. Macquarrie, Jesus Christ in Modern Thought, London, 1990, 366). 
The urge to bring the multiplicity of experience to some form of unity is no doubt an ancient human drive, but it was particularly strong in Romanticism. It clearly distinguishes the German Idealists from earlier rationalists like Descartes, for whom mind and matter (or the thinking self and the external world) represented two distinct realms of reality, whereas for the Idealists they were ultimately one. ${ }^{55}$ Marx too, in his own way, was a monist. 56

Ironically, the nineteenth-century philosophical quest for unity was often found to be compatible with what appeared to be the most unbridled selfassertion, as the basis for unity was taken to reside in the specific vision of some individual philosopher. And indeed Romanticism's exalting of the individual's authority over that of State, Church or tradition turned out to be a potentially sinister development, and in no sense, as had no doubt been intended, only a liberating one. It certainly promoted freedom of self-expression, but such freedom could also be turned in a domineering direction to impose one's own passionately and authentically held convictions on others. Romanticism's encouragement of freedom was thus a double-edged sword. For it could be invoked by enemies of colonialism and lovers of multiculturalism, as well as by totalitarian régimes with irrational ideologies. Romanticism's legacy to the modern world thus appears, to say the least, to be profoundly ambiguous.

Finally, where the Romantics differed markedly from the thinkers of the Enlightenment, was in their more differentiated sense of history. Their respect for the particularity of individual phenomena, their conviction that universal reason could not, unaided, account for the variety of the world's history, set them apart from the Enlightenment which, for them, appeared to assume too static or settled a view of human nature. This shift in the appreciation of history is evident in the positive recognition of humanity's different cultures. But the other side of this coin was the abandonment of any belief in permanently valid human values. Thus, what the Aufklärung may have considered to be eternally true facts about 'human nature', may, the Romantics suspected, have been

55 Solomon, op. cit., p. 6.

56 'Monism' is the term used to describe any system of thought that sees only one substance in all reality, where it is believed that 'all is one' - a saying, attributed from Plato's time to Parmenides, even though the phrase is not found among the fragments of Parmenides, (cf. R. Audi, ed., The Cambridge Dictionary of Philosophy, Cambridge, 1995, 561). Monism is incompatible with the Christian belief in creation ex nihilo, which affirms a real difference between the universe and God, its creative source. 
simply historically conditioned facts about eighteenth-century Western society. ${ }^{57}$ The new, relativistic sense of history that characterizes Romanticism is found in full-blown form in the thinker who for many is the presiding spirit over the movement of modern thought: Georg Wilhelm Friedrich Hegel.

57 See, for example, R. Scruton, A Short History of Modern Philosophy (London, 1995²), $212 f$. 